\title{
SEPSIS BIOMARKERS AND PATHOGEN DETECTION METHODS - STATE OF THE ART
}

\author{
Schmitz P. H. Roland, ${ }^{1}$ Brunkhorst M. Frank ${ }^{1,2}$ \\ ${ }^{1}$ Paul-Martini Research Group, Jena University Hospital, Germany \\ ${ }^{2}$ Center for Clinical Studies (ZKS), Center of Sepsis Control and Care (CSCC), Jena University Hospital, Germany
}

Primljen/Received 28 .02. 2014. god.

Abstract: Evidence-based blood culture testing is of utmost importance for ICU patients with suspected sepsis or organ infection. Knowledge of the etiologic agent (bacteria or fungi) and their susceptibility against antimicrobials enables the clinician to initiate an appropriate antimicrobial therapy and guides diagnostic procedures. This has been shown to reduce mortality, ICU-stay and antibiotic overuse. Whereas microbiological laboratory practice has been highly standardized, shortfalls in the preanalytic procedures in the ICU (indication, timing, volume, numbers, collection of blood cultures) have a significant effect on the diagnostic yield.

Due to system-related drawbacks of molecular diagnostics, i.e. PCR-based pathogen detection, which are arguable sensitivities, the failing of the 'fast time-to-result argument', no solution to establish a comprising antibiogram, still ongoing discussions on the coverage of the target panel, high overall costs, and the lacking of resilient data on clinical utility, non-culture-based NATs do currently not represent an alternative to blood culture testing.

Inflammatory markers are recognized to play an increasingly important role in the diagnosis and monitoring of sepsis. This is partly due to low specificity of clinical symptoms and conventional inflammatory signs for the diagnosis of sepsis but also to a lack of correlation with the severity of the inflammatory response. Elevated serum PCT levels indicate systemic inflammation reliably. PCT is the only sepsis marker that is helpful in the differentiation between infectious and non-infectious causes of organ dysfunction and shock and might support antibiotic therapy.

Keywords: Blood stream infection, blood cultures, sepsis, guidelines, antimicrobial therapy, molecular diagnostics.

\section{INTRODUCTION}

According to the latest data from the Center for Sepsis Control and Care (CSCC) funded by the Federal
Prihvaćen/Accepted 18. 03. 2014. god.

Ministry for Science and Research (BMBF), a total of 174,589 patients developed septic conditions in Germany in 2011 (1). Of these, 87,152 patients had sepsis, 68,551 severe sepsis, and 18,886 septic shock. These figures are based on the new ICD-10 encodings introduced by the German Sepsis Society (DSG) in 2007. The peak age was between 70 and 75 years and 49,198 patients died in hospital. Hospital mortality rate for sepsis was $10.5 \%$, for severe sepsis $41.5 \%$ and $60.5 \%$ for septic shock. These latest figures exceed data on incidence and mortality reported by the German Competence Network SepNet in 2004. Given the increasing age of the population, figures can be expected to continue rising during the coming years. The previous failure of new approaches to the treatment of sepsis is closely related to diagnostic deficits. The time of diagnosis, and thus the early initiation of therapeutic measures is the crucial determinant of the high mortality (2). In both the pre- and intrahospital course of the disease often takes several hours to days to diagnosis and ultimately adequate treatment, since there is currently no reasonable means to predict the transition of a localized infection to severe sepsis. An earlier diagnosis by means of sensitive and specific biomarkers could help to reduce the high mortality and morbidity.

\section{Microbiological diagnosis of sepsis using blood cultures}

The detection of microorganisms using what has recently and rather conspicuously been termed "conventional" or "traditional" BC-testing (in contrast to what is referred to as "modern" molecular biological testing for the pathogen causing sepsis using DNA-testing) is essential for implementation of a causal therapy for infectious diseases brought about by bacteria or fungi. Knowledge of the pathogen and its antibiotic susceptibility enables a targeted antimicrobial therapy to 
Table 1. Guideline-based blood culture testing (acc. to Brunkhorst FM, Seifert H, Kaasch A, Welte T: Shortfalls in the application of blood culture testing in ICU patients with suspected sepsis. DIVI 2010, 1:23)

1. Point of time of blood withdrawal:

- Withdrawal of in minimum two BCs prior to start of antimicrobial therapy otherwise at the end of dosing interval.

- BC should be withdrawn in parallel from 2 different sites or with a gap of several minutes.

- Time point and sampling sites have to be marked onto the data sheet.

- Drawing of double blood volumes and distribution onto 2 BC sets (4 bottles) in case of venipuncture is not recommended. Fresh puncture is obligate.

\section{Aseptic puncture:}

- Hygienic hand disinfection.

- Disposable gloves (not sterile).

- Skin disinfection (e.g., with 70\% alcohol for in minimum 1 minute).

- Puncture without new vein palpation.

- Puncture of peripheral veins.

- No withdrawal from intravenous catheters (risk of contamination).

- Exception: withdrawal of one BC set (anaerobic/aerobic, each) from a catheter suspected for infection and from a peripheral vein.

3. Contamination-free inoculation of $\mathrm{BC}$ bottles:

- Cover removal

- Disinfection of the septum with alcoholic solution (alcohol must not enter the bottle).

- Storage of not inoculated BC bottles at room temperature. Bottles must not be inoculated if cooled.

4. Blood volume required:

- 8-10 ml per bottle.

- Inoculation of the anaerobic flask at first (prevents entry of air bubbles from the tip pf the syringe), aerobic flask at second.

- Special media for pedriatric applications may be inoculated with 1-3 $\mathrm{ml}$ per bottle.

- BC bottles must not be ventilated; bottle barcodes should not be pasted over.

\section{Number of $\mathrm{BCs}$ required:}

- $1 \mathrm{BC}$ consists of $2 \mathrm{BC}$ flasks with aerobic and anaerobic culture media, respectively. If applicable, special media may be used (e.g., for the detection of fungi) additionally.

- Withdrawal of 2 to $4 \mathrm{BCs}$ are recommended. Taking of only $1 \mathrm{BC}$ is not sufficient, given that a negative result permits no preclusion of the presumed infection. A single detection of facultative pathogens (e.g., coagulase-negative Staphylococcus spp.) affords no certain discrimination between contamination and infection.

be conducted and guides the subsequent patient management. This not only improves the prognosis and reduces mortality rates $(3,4,5)$, but also shortens the duration of hospital stay and helps to prevent the overuse of antimicrobials. Blood culture testing is thus clearly the most important evidence-based detection procedure in intensive care. Commercially available BC media permit the growth of almost all microorganisms. Nowadays, it is also customary that BC-testing is performed using equipment with an automated detection system that offers improved susceptibility and shorter detection times. The majority of BCs are positive within the first 12-24 hours. After the detection of a positive BC bottle, gram staining is immediately carried out, subcultures and preliminary susceptibility testing performed. Definitive susceptibility testing to determine the minimum inhibitory concentrations requires a standardized inoculum and is usually performed after overnight incubation resulting in sufficient growth. Subcultures are incubated in aerobic and anaerobic BC-bottles for at least 72 hours. If no bacterial growth can be detected despite positive microscopic identification of bacteria on Gram staining, the incubation time for agar media is increased to 5-7 days in order to enable the identification of slow-growing microorganisms. As procedures for processing BC-bottles in the microbiological laboratory have been standardized to a large degree, guideline-based pre-analytic procedures in intensive care units (indication for obtaining blood cultures, blood collection techniques, transport times) have enormous impact on the diagnostic yield (see Table 1).

\section{Current shortcomings in BC testing}

The reliability of BC-testing for the identification of cultivable microorganisms in blood is high and the contamination rate is below 3\% when guideline-based collection techniques are followed (6). However, the proportion of positive BCs compared to the total number of BCs varies substantially in different retrospective studies but usually ranges between 10 und $25 \%$. In controlled trials, the detection rate for patients with severe sepsis and septic shock is $20-40 \%$ and thus significantly higher. These fluctuations are mainly depend- 
ent on the group of patients being examined, how freely a diagnosis is made, any pre-treatment with antibiotics, the number of blood cultures performed and on adherence to standardized test conditions.

According to a representative study performed by the German National Reference Center for the Surveillance of Nosocomial Infections (NRZ) a total of 223 ICUs provided data on blood culture practice (7). BC pairs taken in 2006 have been 60 (with a huge variation from 3.2 to 680) per 1,000 patient days. The mean primary blood stream infection (BSI) rate was 0.90 per 1,000 patient days and 0.25 BSIs per 1,000 patient days were caused by coagulase negative staphylococci (CNS). The mean central venous catheter (CVC)-BSI rate was 1.40 per $1,000 \mathrm{CVC}$ days. In the univariable analysis the number of blood cultures obtained per 1,000 patients day (referred to as blood culture frequency below) had a significant influence on the CVC-associated BSI-rate, considering either all pathogens $(p=0.001)$ or only the subgroup of CNS-related cases $(p=0.019)$. There was also a significant influence of the BC-frequency on the CVC-BSI-rate considering all pathogens $(p=0.004)$ as well as the subgroup of CNS ( $p=0.018)$. According to the multivariable analysis an increase of the BC-frequency of $100 \mathrm{BCs}$ per 1,000 patient days leads to a 1.27-fold higher incidence density of CVC-BSI with a $95 \%$ confidence interval $(95 \% \mathrm{CI})$ of 1.01-1.26. A further significant risk factor for CVC-BSI was the length of stay in the ICU with an adjusted incidence rate ratio (IRR) of 1.25 (95\% CI 1.15-1.35). The authors concluded that if an external benchmarking of CVC-BSI-rates on ICUs is intended an adjustment according to the $\mathrm{BC}$-frequency is necessary. The BC-frequency itself should be established as a quality indicator in intensive care management.

A survey on blood culture practice performed in 2009 in Germany, the United Kingdom, Italy, and France in 80 microbiological laboratories and 60 ICUs revealed differing estimations on guideline adherence (8). $62 \%$ of the german ICU clinicians saw no problems in handling blood cultures, $8 \%$ criticized transport times bedside to laboratory (guideline recommendation $<12$ hours), which was significantly increased in comparison with the other countries. In contrast, at least $41 \%$ of microbiologists of the same facilities criticized the transport times and 49\% saw shortcomings in pre-analytical quality, e.g. due to false positives by contamination (guideline recommendation $<5 \%$ ). $47 \%$ of questioned microbiologists criticized the low numbers of blood culture sets coming in from the clinic. Cost pressure has been valued rather comparable (Figure 1).

These figures point to a substantial and generally underestimated shortcoming as far as adequate micro-

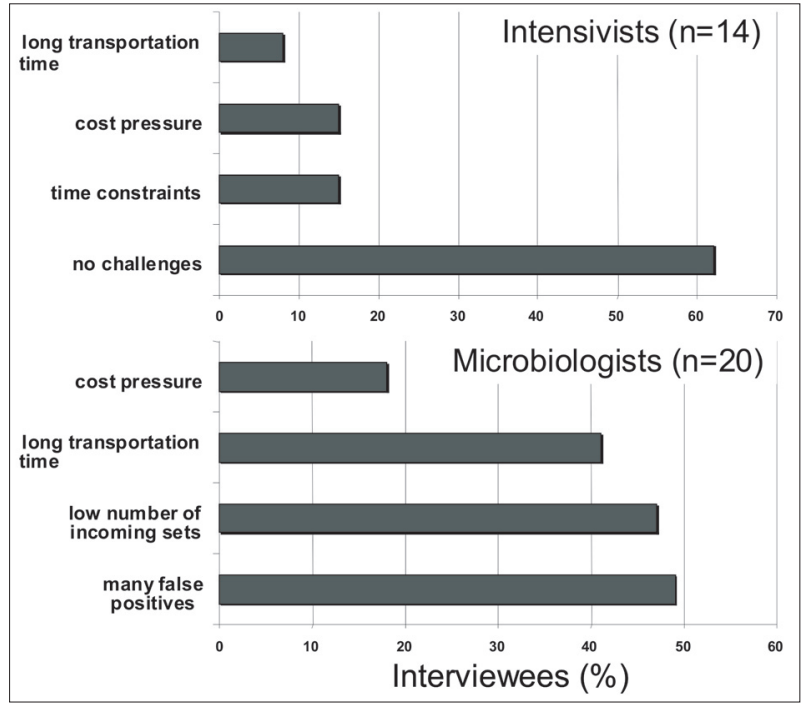

Figure 1. Differences in perceptions of blood culture testing practices between intensivists and microbiologists of the same institutions (according to (8))

biological testing is concerned, and indicate in particular that blood culture testing in German intensive care units is not conducted in accordance with guidelines.

Data on the incidence of bacterial infections vary depending on the patient population and results are dependent on age, underlying illness and a large number of further risk factors, as well as on the clinical department and the size, type and level of healthcare provided by the hospital. In relation to the number of days spent in hospital, the incidence totals $1-3$ cases/1,000 days in hospital (9-13), corresponding to 10-20 ca$\mathrm{ses} / 1,000$ hospital admissions. For patients in intensive care, the incidence is $30-40$ cases/1,000 admissions $(14,15)$. Population-based studies show the incidence of severe bacteremic infections - i.e. those requiring intensive care - to be about 2 cases/10,000 (16).

Despite bacteremic infection, criteria for sepsis are not always fulfilled in elderly persons, patients undergoing immunosuppressive therapy, patients in intensive care (e.g. following polytrauma or burns), in patients with intravascular implants (e.g. prosthetic cardiac valves or stents) and in neonates. In these cases, the indication for blood cultures should be viewed generously. In elderly patients, it should be taken into consideration that acute encephalopathy is often the first sign of sepsis and that patients may remain afebrile. Blood culture should be obtained - in these cases too, as well as in the case of uncontrolled diabetes in an otherwise well-adjusted diabetic patient. In patients with neutropenia, every fever (temperature $>38^{\circ} \mathrm{C}$ ) should be regarded as a possible sign of sepsis and blood cultures should be obtained in this group of patients, the rate of bacteraemia is 20 to $30 \%$. 
Table 2. Drawbacks in routine NAT-based pathogen detection of sepsis pathogens without pre-culturing. $B C$ : blood culture, cfu: colony forming units, MIC: minimal inhibition concentration

- No information on most antimicrobial susceptibility patterns (only available for a small selection, incl. mecA, vanA/B, few ß-lactamases)

- No information on expression status after detection of resistance targets

- No information on drug MIC data

- Sensitivity $\geq \mathbf{3}$ cfu/ml whole blood; expedient target concentration: $<1$ to $5 \mathrm{cfu} / \mathrm{ml}$

- High workload / hands-on-time (depending on assay system)

- Mostly experienced personnel required (depending on assay system)

- Results are not available at start of therapeutic measures (like BC)

- Transport time to lab assumed as long as time-to-incubation for BC - in Germany up to $20 \mathrm{~h}$ to off-site labs

- Clinical significance of targeting nucleic acids vs. whole / viable pathogen cells still under discussion; sensitivity for free / phagocytozed (microbial) DNA not defined

- Origin and clinical significance of targeted microbes ('true positives') arguable; verification by virtual clinical gold standard (sum of clinical plus microbiological evidence) required

- Ongoing discussion on the usefulness of broad-range vs. specific PCR primers; restricted target panel achieved with specific primers (only detection of the most prevalent pathogens) - broad-range primers prone for detection of non-disease associated germs

- High initial investment for devices / lab equipment, high running costs 1 sample currently $\gg 100,-€ \geq 2$ samples are recommended according to sepsis guidelines for blood withdrawal BC

- No replacement of BC feasible -> additional costs / work load

- Only restricted data on clinical utility / patients' benefits available.

\section{Pathogen detection by means of molecular diagnostics}

The non-culture-based identification of pathogens by means of nucleic acid amplification techniques (NAT), such as multiplex-PCR (identification of a limited number of specified pathogens by a defined set of oligonucleotide primers) and broad-range PCR (unre-

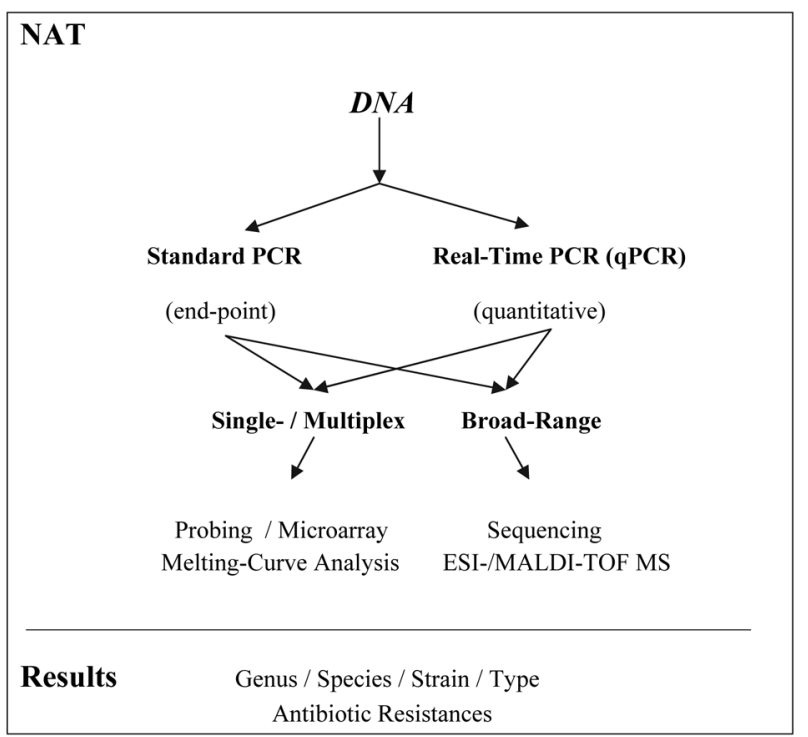

Figure 2. Basic principles of NAT-based applications in bacterial/fungal pathogen detection.

ESI-/MALDI-TOF: electrospray ionization time-/ matrix-assisted laser desorption-ionization time-of-flight mass spectrometry stricted detection of fungal and bacterial DNA by few taxon-specific primers) (Figure 2) is advertised as promising approach to support adequate anti-infective measures at an early stage of sepsis. Amongst most conversant assays for detection of bacterial and fungal DNA in whole blood which are approved for clinical use by European regulatory authorities (i.e. CE-certified) are two multiplex real-time PCR (qPCR) assays. SeptiFast $^{\circledR}$ (Novartis, Basel, Switzerland) simultaneously detects a predefined rather narrow panel of the most important sepsis pathogens by species- and genus-specific primers and subsequent amplicon detection with fluorescent probes. SepsiTest ${ }^{\mathrm{TM}}$ (Molzym, Bremen, Germany) aims at the broad-range detection of bacterial and fungal genomic DNA via $16 \mathrm{~S}$ and $18 \mathrm{~S}$ rRNA gene-based universal primers followed by sequencing of amplicons and gene bank species identification. Abbott (Wiesbaden, Germany) also offers a broad-range system followed by mass spectrometry for species identification (Plex-ID).

\section{Current limitations in PCR-based sepsis pathogen detection}

\section{Sensitivity \& specificity}

Crucial for pathogen detection is the low abundance of pathogens within the blood stream of patients with BSIs. In cases of severe sepsis/septic shock, an about 10 colony forming units (cfu) per $\mathrm{ml}$ of whole blood are to be expected in adults $(17,18)$, within a 
range of 1 to $30 \mathrm{cfu}$ per $\mathrm{ml}(19)$. In contrast, 100 to 300 cfu per $\mathrm{ml}$ have been detected in newborns $(17,20)$. In case of severe sepsis or septic shock, only reduced benefit for the patient's outcome will be achieved by the causative pathogen's identification at the later stages of the disease. Thus, pathogen detection should be initiated as soon as possible at lower bacterial loads ideally down to $<1 \mathrm{cfu} / \mathrm{ml}$ whole blood. Even $3 \mathrm{cfu} / \mathrm{ml}$ marks the lowest limit of detection of the most sensitive NAT-based assays (3 to $100 \mathrm{cfu} / \mathrm{ml}$ detection range (21)) which unfortunately is absolutely in range with frequent contamination loads.

Sensitivity mainly depends on the ratio of target sequence content to background DNA, i.e., particularly human leukocyte DNA. This bulk DNA, co-isolated with microbial pathogen nucleic acids, is the cause for a minute pathogen to human DNA ratio by a factor of $\sim 2 \times 10^{-9} \mathrm{cfu} / \mathrm{ml}$ whole blood, roughly given that 10 genome copies of $\sim 5 \mathrm{fg}$ each are present within $100 \mu \mathrm{g}$ of total DNA isolated from $1 \mathrm{ml}$ whole blood, the reason for low assay sensitivities in the presence of bulk DNA (22). Those drawbacks can be restrictedly conquered by using higher starting material volumes combined with effective background DNA reduction while maintaining the total DNA load per PCR reaction (23, $24,25)$ - which in other words means to increase the target number per total DNA load of the amplification reaction. However, current tools for bulk DNA degradation have not revised the situation: the lowest assay sensitivity stated remains at $3 \mathrm{cfu} / \mathrm{ml}$ whole blood.

Assays using universal primers are in part compromised by their high sensitivities (within constrains mentioned above) due to the fact, that the addressed targets are often present in multiple copies (e.g., panbacterial $16 \mathrm{~S}, 5 \mathrm{~S}, 23 \mathrm{~S}$ rDNA/RNA or panfungal $8 \mathrm{~S}, 18 \mathrm{~S}, 5.8 \mathrm{~S}$, $28 \mathrm{~S}$ rDNA / RNA targeting) but more or less without narrowing possible outcomes. Respective (PCR) primers have been proven to be suitable even for nucleic acid trace detection in diagnostic consumables (26-29), contaminated disinfectants, antiseptics, and BC media (30), or introduced via applying routine sample withdrawal techniques, causing false-positive results. Of major concern in sepsis diagnostics are clinically irrelevant results of non-disease-associated transient bacteraemia, the inability to distinguish between DNA from non-viable, non-active, or dead pathogen cells, or free circulating versus phagocytised DNA in immuno-competent host cells in cases of microbial DNAemia.

Circulation of translocated microbial DNA or the transient presence of bacteria in blood not associated with the disease have been proven in vivo (31). Culture-positive bacteraemia was reported after tooth brushing and other dental measures as transient translocations of mucosal colonizing microorganisms due to min- imal manipulations already decades ago $(32,33)$. Moreover, isolation of bacteria in asymptomatic blood donors and even transient fungaemia without apparent clinical significance has been repeatedly reported (34, 35). Pure microbial background DNA has been detected in the blood of healthy individuals $(36,37)$ and asymptomatic blood cell donors (38) but no resilient information is available for the mean value of whole blood microbial background DNA load of healthy individuals. This indicates the range of risks to obtain false-positives and the difficulties to distinguish them from true-positives. However, origin and clinical significance of 'false-positive' samples are often ambiguous and might belong to yet unbeknown host-pathogen interactions (39). Concluding, non-specific PCR protocols are prone for the detection of non-disease associated germs but also promise to facilitate the finding of microorganisms that are found less frequently, even yet unknown, or generally non-cultivable (17) and might therefore be of high scientific relevance but rather objectionable in sepsis causative species verification.

The panel of multiplex PCR assays with specific primers is limited due to primer interactions / heteromer formation and technical limitations (e.g., fluorescence dyes), which sets margins to the amount of targets detectable within one PCR tube or primer pool. Otherwise, a setting of too many individual PCR reactions for investigation of a single specimen would lead to high costs and workload. It has been consequently proposed, that PCR detection in clinical diagnostics should focus only on those pathogens or resistance determinants that are not covered by guideline recommended treatment regimens and that have been identified as the major cause of inappropriate treatment (40). The authors stated that multiplex panels should be scaled down by high conservation of its individual primers. Such a narrower assay would be more cost effective, may achieve higher accuracy due to reduced intra-test interference, and would better address current and emerging clinical needs. However, clinicians rightly call for all-embracing diagnostic approaches: what would be the benefit of an assay which gives only an aperture of the targets of relevance and necessitates continuation of the traditional clinical course in parallel to cover all diagnostic outcomes?

\section{Shortfalls in the detection of antibiotic resistances}

Clinical and commercial success of NAT-based assays mainly depend on their ability to compete with the standard (i.e., cultural) methods in antibiotic resistance detection. This becomes increasingly important in the context of rising broad-spectrum resistance in Gram-ne- 
gative rods, particularly for carbapenemase-expressing pathogens, like Klebsiella spp. and multi-drug resistant Acinetobacter baumannii $(41,42)$. Fast identification of MRSA or VRE may be feasible by molecular methods since methicillin and vancomycin resistances are encoded by a limited number of known genotypes. However, many types of bacterial resistance base on several distinct point mutations, e.g. Penicillin-resistance in $\mathrm{Pneu-}$ mococcus spp., and more than 300 extended-spectrum ß-lactamases (ESBL) described so far for distinct Gram-negatives are encoded by a huge and still evolving variety of genotypes. Moreover, phenotypic resistances and the number of various regulatory genes, whose role in resistance expression remain elusive, precludes simple molecular- (or proteomic-) based economic detection approaches for routine purposes. Therefore, molecular detection of the most prominent bacterial antibiotic resistance-mediating target genes, one of the most relevant aspects for a timely confirmation or correction of the initial therapeutic regimen, will be restricted to a limited number of resistance types in the foreseeable future and broad antibiograms remain subject only to the cultural approach convicting the molecular methods to be costly adjuncts to the traditional way of action.

Furthermore, add-on information on antibiotic minimal inhibition concentrations (MIC) becomes increasingly important. Therapeutic drug monitoring (TDM) is discussed as a key intervention to improve outcomes in patients with sepsis and septic shock. In these patients, pharmacokinetics of $\beta$-lactam antibiotics may be altered due to dynamic, unpredictable pathophysiological changes and significant increases in the volume of distribution and/or augmented renal (drug) clearance (ARC) $(43,44,45)$. When $ß$-lactam antibiotics are applied uncontrolled, pharmacokinetic changes can result in sub-therapeutic plasma concentrations, treatment failure, and the development of antibiotic resistance. Individualized dose optimization to achieve drug concentrations above the MIC of the infecting pathogen is demanded. Changes in plasma concentration were also monitored in a recent meta-analysis on the outcomes of extended or continuous versus short-term intravenous application of first-line drugs (46) and in a multicenter trial on continuous infusion versus intermittent bolus therapy (47). Aside from the respective findings there is growing evidence for a high potential in an individualized modification of the anti-microbial therapy. Knowledge of the MIC data of the underlying presumed pathogen could substantially improve the patient's outcome but is only achievable via culturing and not by NAT.

\section{Transport vs. time-to-results}

A weighty argument to adopt molecular tools in sepsis diagnostic routine is the promise to deliver ther- apy-relevant results much faster than via cultural workflows. Beside the fact that patients with advanced community-acquired sepsis (about $30 \%$ of sepsis incidences) are in part already empirically treated with broad-spectrum antibiotics when they enter the emergency units (48), already a (e.g.) 2 hour time-to-result, which is currently not achievable at all directly from whole blood, would deliver NAT results too late to direct immediate anti-infective measures with first-line drugs. The physician's attendance to change an initiated therapeutic measure then decreases steadily within the first days. In most cases, hospital-acquired (nosocomial) early-stage and primary sepsis (e.g. catheter-associated sepsis) is handled under constant surveillance by cultural methods and timely pressure is lower to anticipate a meaningful cultural or NAT-based result on the underlying infective agent. However, NAT could positively impact pathogen detection in cases of nosocomial septic infections where patients at risk, i.e. patients with artificial ventilation, urinary or central-venous catheters, peripheral venous cannulation, immunosuppression, or surgery, are monitored broadly from the beginning of the period of risk where sepsis could be diagnosed at an early stage with a higher likelihood of recovery (if other premises would be solved).

Achievements in time-to-result are often biased by limitations in sample transport between bedside and lab as revealed by the international survey on $\mathrm{BC}$ diagnostics cited above (8). Time-to-incubation for $\mathrm{BC}$ depends on the way of sample transportation, opening hours of the microbiological labs, BC management outside these time frames, and ranges from $2 \mathrm{~h}$ in the UK and German on-site laboratories to $20 \mathrm{~h}$ in German remote labs. The benefit from shortening the time-to-result due to technical accomplishments is hampered due to opposing sample logistics. This without regard to an aspired batch-wise analysis of samples, still high turnaround times, in part low sample throughput, high technical complexity, and (for most clinical facilities) prohibitive overall costs $(>100$ $€ /$ sample). Expectedly, even for the as to be rapid advertised assay SeptiFast ${ }^{\circledR}$, the median time-to-results in a 2009 retrospective clinical trial were 18 hours, with a minimum of 6.75 hours and a maximum of $74 \mathrm{~h}$ (samples were collected at the beginning of the weekend) when samples were taken twice a day, and with a median time of 26.25 hours, a minimum of 6.75 hours and a maximum of 79 hours with a once daily analysis (49). Notably, the setting corresponds to on-site lab availability. However, these observations challenge recent data on clinical utility of the assay (50). To give a further example, Bloos and colleagues revealed a median time-to-positivity of 24.2 hours for their NAT and 68 hours for BC, also with a lab on-site (51). Depending on technician availability, the 
Table 3. Clinical markers for the enhancement of sepsis diagnosis.

ATG: anti-human T-lymphocyte globulin; TNF- $\alpha$ : tumor necrosis factor $\alpha$

\begin{tabular}{|c|c|c|c|c|}
\hline & \multirow{2}{*}{$\begin{array}{l}\text { Specificity } \\
\text { for infection }\end{array}$} & \multirow{2}{*}{$\begin{array}{l}\text { Sensitivity for } \\
\text { non-infectious } \\
\text { inflammation }\end{array}$} & \multicolumn{2}{|c|}{ Clinical utility as sepsis marker } \\
\hline & & & Pros & Cons \\
\hline $\begin{array}{l}\text { Procalcitonin } \\
\text { (PCT) }\end{array}$ & ++++ & + & $\begin{array}{l}\text { - high specificity and sensitivity } \\
\text { for sepsis } \\
\text { - good correlation with severity code } \\
\text { - fast induction }(<2 \mathrm{~h}) \\
\text { - high stability } \\
\text { - half-live period } 24 \mathrm{~h} \\
\text { - broad biological time span }\end{array}$ & $\begin{array}{l}\text { - possibly increased in cases } \\
\text { of severe sepsis due to: } \\
\text { - comprehensive surgical } \\
\text { operations } \\
\text { - } \text { poly-trauma } \\
\text { - hemorrhagic shock } \\
\text { - cardiogenic shock } \\
\text { - cardiopulmonary bypass } \\
\text { - } \text { birth stress } \\
\text { - severe burns } \\
\text { - immunosuppressants } \\
\text { - } \text { (e.g., TNF- } \alpha, \text { ATG) } \\
\text { - cost-intencer } \\
\text { - slow induction in neonatal sepsis }\end{array}$ \\
\hline $\begin{array}{l}\text { C-reactive } \\
\text { protein (CRP) }\end{array}$ & + & ++ & - relatively cost-effective & $\begin{array}{l}\text { - low specificity } \\
\text { - slow induction (peak after } 48 \text { h) } \\
\text { - small biological span } \\
\text { - no correlation with severety }\end{array}$ \\
\hline $\begin{array}{l}\text { Interleukin-6 } \\
\text { (IL-6) }\end{array}$ & + & ++++ & $\begin{array}{l}\text { — high sensitivity } \\
\text { — fast induction (range of minutes) } \\
\text { — broad biological time span }\end{array}$ & $\begin{array}{l}\text { - low specificity } \\
\text { - short half-live time (min) } \\
\text { - low biostability } \\
\text { - cost-intensive }\end{array}$ \\
\hline $\begin{array}{l}\text { Lipopolysac- } \\
\text { charide- } \\
\text { binding protein } \\
\text { (LBP) }\end{array}$ & + & +t & $\begin{array}{l}\text { - high sensitivity } \\
\text { - long half-live time (> } 48 \text { h) }\end{array}$ & $\begin{array}{l}\text { - low specificity } \\
\text { - slow induction } \\
\text { - cost-intensive }\end{array}$ \\
\hline $\begin{array}{l}\text { Leukocyte } \\
\text { count }\end{array}$ & + & + & $\begin{array}{l}\text { - simple } \\
\text { - cost-effective }\end{array}$ & — low specificity \\
\hline Temperature & + & + & $\begin{array}{l}\text { - simple } \\
\text { - cost-effective }\end{array}$ & — low specificity \\
\hline
\end{tabular}

NAT median time-to-positivity increased up to 53.5 hours on weekends.

\section{CONCLUSION}

Over the last years, growing evidence appeared which supported the add-on value of NAT-based commercials as adjuncts to culture methods in an early but even faster detection of true positives and designated antibiotic resistance markers. Positive influence on time-to-initiation of directed anti-infective measures, mortality, length-of-stay in hospital, overall costs and administration of broad-spectrum antibiotics have also been stated. Selected assays might have gained significant added value in enabling evidence-based antibiotic stewardship in exceptional cases. However, due to system-related drawbacks like arguable sensitivities in adult sepsis, the failing of the 'fast time-to-result argument' (especially in Germany), no solution to establish a comprising antibiogram with additional information on MIC data, the ongoing discussions on the coverage of the target panel, significantly too high overall costs, and the lacking of resilient data on clinical utility,(for a summary on drawbacks see Table 2) non-culture-based NATs do currently not represent an alternative to $\mathrm{BC}$ testing and it is not yet possible to derive any recommendations for clinical practice.

\section{Sepsis markers - a gain of time!}

An early diagnosis using sensitive and specific biochemical or immunological markers could help to reduce the high mortality and morbidity associated with 
sepsis. Conventional parameters such as body temperature, heart rate and white blood cells (WBCs) are inadequate parameters to describe the complexity and the magnitude of the inflammatory host response. Apart from insufficient tissue oxygenation, a major risk factor responsible for organ dysfunction is systemic inflammation. This leads to various alterations in cellular metabolism of immune competent and parenchymatous cells (induction of pro- and anti-inflammatory mediators (interleukins IL-1, IL-2, IL-6, IL-8, IL-10, as well as factors like tumor necrosis factor $\alpha$, (TNF- $\alpha)$ ), metabolites (NO, neopterin, formation of oxidative radicals, alteration of immunologic reactivity (HLA-DR), synthesis of proteins and functional proteins (procalcitonin (PCT), C-reactive protein (CRP), other acute phase proteins), induction of apoptosis). To determine the course and extent of systemic inflammation is therefore crucial to assess the risk profile of a patient, therapeutic success of such measures and prognostic significance of the illness. Without additional parameters, the assessment of the degree of inflammation based simply on clinical symptoms or on the development of organ dysfunction is often unreliable. There are few parameters used in clinical diagnostics that are closely associated with the degree of inflammation including interleukin-6, interleukin-8, PCT and with certain limitations also C-reactive protein (see Table 3). To date, most of the investigations are limited to case reports or cohort studies with underpowered sample size, thus the quality of the studies are often compromised. The use of different definitions for sepsis and lack of continuous daily parameters during the course of illness are partly accountable for conflicting findings. Well designed, controlled studies with convincing statements concerning sensitivity, specificity and receiver operating characteristics (ROC) are still rare. A variety of parameters are not currently used for diagnostic purposes in routine health care due to limitations such as very short biological half-life, lack of standardized testing, or accumulation in renal insufficiency. Although numerous bioactive peptides could possibly be used as bio-markers during the course of sepsis, many of them are not reliably detected by conventional assays due to their receptor-related protein-binding sites and degradation by proteases (in vivo and in vitro). For these reasons, many parameters have only a limited value e.g. markers of the endothelium, and endothelial dysfunction (adhesion molecules and their ligands), cytokines such as TNF- $\alpha$ and IL-1, various acute phase proteins (transferrin, LBP), PMN elastase, neopterin, phospholipase A2, platelet-activating factor acetylhydrolase (PAF-AH), complement $\mathrm{C} 3 \mathrm{a}$, and others. In clinical practice, some non-specific parameters may be helpful as part of a routine laboratory monitoring and should not be underesti- mated. These include clotting parameters (Quick, PTT, platelet count) and metabolic parameters and classical signs of inflammation (lactate, leucocytes, temperature).

\section{Procalcitonin (PCT)}

PCT $(13 \mathrm{kDa})$ is a precursor of the hormone calcitonin and is normally produced by the C-cells of the thyroid gland. In healthy individuals PCT is released into the blood stream in form of calcitonin only after endopeptide cleavage. Although plasma levels of PCT are very low under normal conditions $(<0.1 \mathrm{ng} / \mathrm{ml})$, they may rise up to 5,000-10,000 fold in patients with severe sepsis while the plasma calcitonin concentrations remain within the normal range (52). Unlike calcitonin which has a half-life of about 10 minutes, PCT has an increased half-life of $\sim 24$ hours.

Although the exact biological role of PCT and its origin are still not clear, it appears that extrathyroid tissue is also able to secrete PCT systemically and secretion generally correlates well with the degree of sepsis. There are several conditions that may stimulate PCT release including bacterial infection and non-infectious stimuli, e.g. major surgery, multiple trauma and burns, though the increase is most pronounced in severe sepsis and septic shock. PCT is detectable in the blood as early as 2 hours after the microbial stimulus and therefore is "faster" than CRP, but "slower" than the cytokines (53). PCT has a very high biostability ex vivo with over $90 \%$ of activity detectable in plasma samples even after 12 hours storage at room temperature. Moreover, PCT obviously does not bind to receptors or other proteins, and so indeed can be captured by conventional immunoassays.

A comprehensive meta-analysis confirmed the role of PCT as a helpful biomarker for the differentiation of sepsis and systemic inflammatory response syndrome (SIRS) with non-infectious origin in critically ill in 2013. However, the confinement is the case history, comprising medical examination, and microbiological assessment (54). 30 individual studies with in total 3,244 patients were examined. Bivariate analysis resulted in a medium PCT sensitivity of 0.77 (95\% CI $0.72-0.81)$ and a specificity of 0.79 (95\% CI $0.74-$ $-0.84)$. ROC curve analysis unfolded an area under curve of 0.85 (95\% CI $0.81-0.88$ ). A further meta-analysis of seven studies with in total 1,075 patients suffering from sepsis and septic shock came to the conclusion, that PCT-driven therapy is suited to support antibiotic regimens and surgical interventions but without significantly influencing overall mortality (55): whether hospital nor 28-day mortality differed between the groups of patients with PCT-driven therapy and with standard care. However, length of antibiotic adminis- 
tration was significantly shortened within the first group, although length of ICU- and hospital stay did not vary in both groups.

Record of PCT leves in serum at an early stage are recommended within the current sepsis guidelines to rule out severe sepsis and to consequently confirm diagnosis (56). Conversely, in case of localized infections without systemic inflammation, there is only a slight increase of PCT levels despite considerably increased CRP values. Likewise, PCT concentrations decrease in patients with severe sepsis following an adequate therapy even when the focus is not completely eradicated. In these patients, however, further antibiotic treatment or surgical restoration of the focus may be needed despite normal PCT concentrations. While the predictive value of PCT in critically ill patients has been demonstrated in several studies, this is not the case for TNF- $\alpha$, IL-6, or CRP.

High PCT levels are closely associated with the occurrence of organ dysfunction distant from the site of infection. This marker seems able to distinguish an infectious from a non-infectious etiology of generalized inflammation, which in turn may have far-reaching therapeutic implications. PCT plasma concentrations are also increased in case of hemodynamic failure e.g. due to a translocation of endotoxin after major surgery, polytrauma, or cardiogenic shock. In this situation daily monitoring of PCT plasma concentrations can be helpful for early detection of possible septic complications.

\section{Control of antimicrobial therapy and monitoring of therapeutic interventions}

Strategies to reduce ICU mortality rate in patients with bacteraemia and sepsis should include an individual early risk profile and correct intravenous antibiotic therapy based on microbiological resistance patterns (57). Antibiotic therapy should be initiated rapidly, possibly within an hour after the onset of severe sepsis or septic shock (58). The German Sepsis Society (DSG) recently recommended a regular evaluation of antibiotic regimes every 48-72 hours based on clinical and microbiological criteria in order to narrow down the antimicrobial spectrum, the risk of resistance, the toxicity, and the duration of antibiotic therapy depending on clinical response and thus reduce costs (58). These measures are in practice often difficult to implement because the existing "clinical and microbiological" criteria are still inadequate. An improved diagnostic is therefore highly recommended. New and more sensitive PCT assays with a functional analytic sensitivity of 0.04 $\mathrm{ng} / \mathrm{ml}$ allow for diagnosis and monitoring of non-septic weak infections in threshold ranges below $0.5 \mathrm{ng} / \mathrm{ml}$. A randomised study with patients with community-acqu- ired sepsis showed that length of antibiotic regimen could be decreased from 13 to 6 days by application of a PCT-driven algorithm without compromising the patient's outcome (59). The same authors proved a significant reduction of length of antibiotics administration and dosage after one-time PCT determination in 243 medium ill patients with ventilator-associated pneumonia ( $83 \%$ vs. $44 \%$ and 12.8 vs. 10.9 days, respectively) (60). The results may not be transferable onto critically ill but suggest the potential of such algorithms.

In 2009, the ProHOSP study confirmed a significant reduction of antibiotics usage and antibiotic-associated side-effects in the group of PCT-driven therapy in a study with patients suffering from infections of the lower respiratory tract (61). The algorithm used had provided defined threshold values for administration and stop of the anti-infective regime.

In another prospective randomized study conducted by the University Hospital Geneva, it was demonstrated for the first time that a protocol based on serial PCT measurement compared to a routine decision algorithm could reduce antibiotic treatment duration by 3.5 days (median) in patients with severe sepsis without apparent harm. Furthermore, the length of ICU stay in patients assigned to the PCT group was reduced by 2 days (62).

\section{Interleukin-6}

Interleukin-6 and interleukin- 8 show positive correlation with severity and prognosis of patients with sepsis. In patients with sepsis, interleukin-6 (IL-6) concentrations increase 1,000-fold. Furthermore, increased IL-6 values over $1,000 \mathrm{pg} / \mathrm{ml}$ have been proposed as an indication for an immunomodulatory monoclonal antibody therapy. In the MONARCS study, a randomized controlled sepsis trial on monoclonal anti-TNF, increased serum IL-6 levels over 1,000 pg/ml were associated with a greater risk for organ dysfunction and mortality (mortality $47.7 \%$ in IL-6 $>1,000 \mathrm{pg} / \mathrm{ml}$ vs. $28.6 \%$ for IL- $6<1,000 \mathrm{pg} / \mathrm{ml}$ ) (63). Interestingly, in the PROWESS study that led the regulatory authority to license the recombinant human activated Protein C, high IL-6 levels $(600 \mathrm{pg} / \mathrm{ml})$ did not show prognostic significance in the post-hoc analysis (64).

Unlike TNF- $\alpha$, the detection of IL-6 is not affected by the presence of a soluble receptor. The marked inter-individual variations in plasma IL-6 release due to phase-dependent activation of anti-inflammatory cytokines suggest that IL-6 measurements have relevance for the intra-individual assessments during the course of illness. Furthermore, the specificity of IL-6 is rather low in case of severe infections but the factor 
may display advantages in neonatal sepsis due to a faster induction.

\section{C-reactive protein (CRP)}

C-reactive protein is an acute-phase protein produced by hepatocytes, which is activated by IL-6 or IL-1 and may act as a mediator and inhibitor of inflammation. It activates the complement cascade reaction after binding to bacterial polysaccharides or lysed cell membranes in response to infection and trauma. C-reactive protein prevents neutrophil adhesion to endothelial cells, inhibits the generation of superoxide anion and increases IL-1 receptor antagonist. CRP is the most commonly used biochemical marker to measure both the presence and amplitude of the inflammatory response. A high positive predictive value of CRP has been reported in a study of sepsis patients, e.g. SIRS due to an infection but without organ dysfunction (58). In other studies of patients with severe sepsis, e.g. with organ dysfunction, however, CRP failed to show meaningful correlation both for early diagnosis as well as in assessment of severity. In contrast to cytokines and PCT levels, the levels of CRP peaked only after 24 hours (62).

CRP concentration increases in response to mild microbial infections and in a variety of diseases. Elevated CRP concentrations over several days are usually observed even after successful eradication of the infectious focus. CRP has been shown to be a valuable enrichment for the monitoring of inflammatory change of local infections during effective antibiotic treatment.

\section{CONCLUSION FOR PRACTICE}

Inflammatory markers are recognized to play an increasingly important role in the diagnosis and monitoring of sepsis. This is partly due to low specificity of clinical symptoms and conventional inflammatory signs (high or low temperature, leukocytosis, low platelets) for the diagnosis of sepsis but also to a lack of correlation with the severity of the inflammatory response. At present, a combined approach can facilitate improved diagnosis and monitoring of sepsis. Clinical signs, scoring systems of organ dysfunction (e.g. SOFA score) and inflammatory markers can be used for diagnosis and follow-up. The potential clinical usefulness of current markers can be outlined as follows: (i) sensitivity and specificity of PCT for sepsis is better than that of CRP, IL-6, IL-8 and conventional parameters like leucocyte count and body temperature. (ii) to date it is the only sepsis marker that is helpful in the differentiation between infectious and non-infectious causes of organ dysfunction and shock. (iii) several studies indicate that PCT is much more elevated in bacterial infections compared to viral infections. (iv) a number of studies demonstrate that the course of PCT serum levels represent the success of infection or sepsis treatment early on and better than CRP. Furthermore, more recent studies strongly suggest that in patients with suspected respiratory tract infections and patients with community acquired pneumonia PCT is helpful to guide antibiotic therapy. PCT guided indication for antibiotics resulted in a 50\% reduction in the use as well as in the duration of therapy with antibiotics.

\section{Acknowledgements}

The project is supported by the Paul-Martini-Sepsis Research Group, funded by the Thuringian Ministry of Education, Science and Culture (ProExcellence; grant PE 108-2); the public funded Thuringian Foundation for Technology, Innovation and Research (STIFT) and the German Sepsis Society (GSS); the Jena Center of Sepsis Control and Care (CSCC), funded by the German Ministry of Education and Research (BMBF; grant 01 EO 1002).
Abbreviations
BC - blood culture
cfu - colony forming units
CRP - C-reactive protein
ICU - intensive care unit
IL-6 - interleukin-6
NAT - nucleic acid amplification techniques
PCT - procalcitonin

\title{
Sažetak
}

\section{BIOMARKERI SEPSE I METODE ZA DETEKCIJU PATOGENA}

\author{
Schmitz P. H. Roland, ${ }^{1}$ Brunkhorst M. Frank ${ }^{1,2}$ \\ ${ }^{1}$ Paul-Martini Research Group, Jena University Hospital, Germany \\ ${ }^{2}$ Center for Clinical Studies (ZKS), Center of Sepsis Control and Care (CSCC), Jena University Hospital, Germany
}

Hemokultura je od velike važnosti za pacijente intenzivne nege kod kojih se sumnja na sepsu ili infekciju organa. Poznavanje etiološkog agensa (bakterija ili gljivica) i njegove osetljivosti na antimikrobne lekove 
omogućava lekaru da inicira odgovarajuću antimikrobnu terapiju i sprovodi odgovarajuće dijagnostičke procedure. Ovo je pokazalo da smanjuje smrtnost, dužinu boravka na intenzivnoj nezi i preteranu upotrebu antibiotika. Dok je praksa mikrobiološke laboratorije visoko standardizovana, nedostaci u preanalitičkim procesima $\mathrm{u}$ intenzivnoj nezi (indikacija, pravovremensot, prikupljanje krvi) imaju značajan uticaj na dijagnostiku.

Zbog nedostataka molekularne dijagnostike, kao što je na primer PCR detekcija patogena čija je senzitivnost diskutabilna, dužeg čekanja rezultata, nepostojanja rešenja za utvrđivanje sveobuhvatnog antibiograma, još uvek aktuelne diskusije oko ovog panela, velikih troškova i nepostojanja podataka o kliničkom zna-

\section{REFERENCES}

1. Heublein S, Hartmann M, Hagel S, Hutagalung R, Brunkhorst FM. Epidemiology of sepsis in German hospitals derived from administrative databases. 6th International Congress on Sepsis and Multiorgan Dysfunction, September 4-6 2013, Weimar. Infection. 2013; 41(1): 7-23.

2. Levy MM, Fink MP, Marshall JC, et al. SCCM/ESICM/ /ACCP/ATS/SIS for the International Sepsis Definitions Conference. $2001 \mathrm{SCCM} / \mathrm{ESICM} / \mathrm{ACCP} / \mathrm{ATS} / \mathrm{SIS}$ International Sepsis Definitions Conference. Intensive Care Med. 2003; 29(4): 530-8.

3. Ibrahim EH, Sherman G, Ward S, Fraser VJ, Kollef $\mathrm{MH}$. The influence of inadequate antimicrobial treatment of bloodstream infections on patient outcomes in the ICU setting. Chest. 2000; 118(1): 146-55.

4. MacArthur RD, Miller M, Albertson T, et al. Adequacy of early empiric antibiotic treatment and survival in severe sepsis: experience from the MONARCS trial. Clin Infect Dis. 2004; 38(2): 284-8.

5. Weinstein MP, Reller LB, Murphy JR, Lichtenstein KA. The clinical significance of positive blood cultures: a comprehensive analysis of 500 episodes of bacteremia and fungemia in adults. I. Laboratory and epidemiologic observations. Rev Infect Dis. 1983; 5(1): 35-53.

6. Spitalnic SJ, Woolard RH, Mermel LA. The significance of changing needles when inoculating blood cultures: a meta-analysis. Clin Infect Dis. 1995; 21(5): 1103-6.

7. Gastmeier P, Schwab F, Behnke M, Geffers C. The median number of blood culture Less blood culture samples: less infections? Anaesthesist. 2011; 60(10): 902-7.

8. Schmitz RPH, Keller PM, Baier M, Hagel S, Pletz MW, Brunkhorst FM. Quality of blood culture testing - a survey in intensive care units and microbiological laboratories across four European countries. Critical Care. 2013; 17(5): R248.

9. Diekema DJ, Beekmann SE, Chapin KC, Morel KA, Munson E, Doern GV. Epidemiology and outcome of nosocomial and community-onset bloodstream infection. J Clin Microbiol. 2003; 41(8): 3655-60.

10. Elhanan G, Raz R, Pitlik SD, et al. Bacteraemia in a community and a university hospital. J Antimicrob Chemother. 1995; 36(4): 681-95.

11. Geerdes HF, Ziegler D, Lode H, et al. Septicemia in 980 patients at a university hospital in Berlin: prospective studi- čaju, NAT testiranje još uvek ne predstavlja alternativu hemokulturi.

Inflamatorni markeri igraju značajnu ulogu u dijagnozi i praćenju sepse. Razlog tome je delimično nespecifičnost kliničkih simptoma i konvencionalnih znakova zapaljenja za dijagnozu sepse, ali takođe i nedostatak njihove korelacije sa težinom inflamatornog odgovora. Povišen nivo prokalcitonina (PCT) u serumu je siguran indikator sistemskog zapaljenja. PCT je jedini marker sepse koji je od pomoći u diferencijaciji između infektivnih i neinfektivnih uzroka disfunkcije organa i šoka i može podržati antibiotsku terapiju.

Ključne reči: Infekcija krvi, kultura krvi, sepsa, antimikrobna terapija, molekularna dijagnostika.

es during 4 selected years between 1979 and 1989. Clin Infect Dis. 1992; 15(6): 991-1002.

12. Laffer RR, Frei R, Widmer AF. Epidemiology of septicemias in a university hospital over 5 years. Schweiz Med Wochenschr. 2000; 130(41): 1471-8.

13. Scheckler WE, Bobula JA, Beamsley MB, Hadden ST. Bloodstream infections in a community hospital: a 25-year followup. Infect Control Hosp Epidemiol. 2003; 24(12): 936-41.

14. Brun-Buisson C, Doyon F, Carlet J, et al. Incidence, risk factors, and outcome of severe sepsis and septic shock in adults. A multicenter prospective study in intensive care units. French ICU Group for Severe Sepsis. JAMA. 1995; 274(12): 968-74.

15. Hugonnet S, Harbarth S, Ferriere K, Ricou B, Suter P, Pittet D. Bacteremic sepsis in intensive care: temporal trends in incidence, organ dysfunction, and prognosis. Crit Care Med. 2003; 31(2): 390-4.

16. Laupland KB, Gregson DB, Zygun DA, Doig CJ, Mortis G, Church DL. Severe bloodstream infections: a population-based assessment. Crit Care Med. 2004; 32(4): 992-7.

17. Klouche M, Schröder U. Rapid methods for diagnosis of bloodstream infections. Clin Chem Lab Med. 2008; 46(7): 888-908.

18. Kreger BE, Craven DE, Carling PC, McCabe WR. Gram-negative bacteraemia. III. Reassessment of etiology, epidemiology and ecology in 612 patients. Am J Med. 1980; 68(3): $332-3$.

19. Yagupsky P, Nolte FS. Quantitative aspects of septicaemia. Clin Microbiol Rev. 1990; 3(3): 269-79.

20. Jordan JA, Durso MB. Real-time polymerase chain reaction for detecting bacterial DNA directly from blood of neonates being evaluated for sepsis. J Mol Diagn. 2005; 7(5): 575-81.

21. Lehmann LE, Hunfeld KP, Emrich T, et al. A multiplex real-time PCR assay for rapid detection and differentiation of 25 bacterial and fungal pathogens from whole blood samples. Med Microbiol Immunol. 2008; 197(3): 313-24.

22. Handschur M, Karlic H, Hertel C, Pfeilstöcker M, Haslberger AG. Preanalytic removal of human DNA eliminates false signals in general 16S rDNA PCR monitoring of bacterial pathogens in blood. Comp Immunol Microbiol Infect Dis. 2009; 32(3): 207-19.

23. Wiesinger-Mayr H, Jordana-Lluch E, Martró E, Schoenthaler S, Noehammer C. Establishment of a semi-auto-mated 
pathogen DNA isolation from whole blood and comparison with commercially available kits. J Microbiol Methods. 2011; 85(3): 206-13.

24. Horz HP, Scheer S, Vianna ME, Conrads G. New methods for selective isolation of bacterial DNA from human clinical specimens. Anaerobe. 2010; 16(1): 47-53.

25. Horz HP, Scheer S, Huenger F, Vianna ME, Conrads G. Selective isolation of bacterial DNA from human clinical specimens, J Microbiol Methods. 2008; 72(1): 98-102.

26. Ehricht R, Hotzel H, Sachse K, Slickers P. Risidual DNA in thermostable DNA polymerases - a cause of irritation in diagnostic PCR and microarray assays. Biologicals. 2007; 35(2): 145-7.

27. Koncan R, Valverde A, Morosini MI, et al. Learning from mistakes: Taq polymerase contaminated with beta-lactamase sequences results in false emergence of Streptococcus pneumoniae containing TEM. J Antimicrob Chemother. 2007; 60(3): 702-3.

28. Peters RP, Mohammadi T, Vandenbroucke-Grauls CM, Danner SA, van Agtmael MA, Savelkoul PH. Detection of bacterial DNA in blood samples from febrile patients: underestimated infection or emerging contamination? Immunol Med Microbiol. 2004; 42(2): 249-53.

29. van der Zee A, Peeters M, de Jong C, et al. Qiagen DNA extraction kits for sample preparation for legionella PCR are not suitable for diagnostic purposes. J Clin Microbiol. 2002; 40(3): 1126.

30. Oie S, Kamiya A. Microbial contamination of antiseptics and disinfectants. Am J Infect Control. 1996; 24(5): 389-95.

31. Dagan R, Shriker O, Hazan I, et al. Prospective study to determine clinical relevance of detection of pneumococcal DNA in sera of children by PCR. J Clin Microbiol. 1998; 36(3): 669-73.

32. Berger SA, Weitzman S, Edberg SC, Casey JI. Bacteremia after the use of an oral irrigation device. A controlled study in subjects with normal-appearing gingiva: comparison with use of toothbrush. Ann Intern Med. 1974; 80(4): 510-1.

33. Tomás I, Alvarez M, Limeres J, Potel C, Medina J, Diz P. Prevalence, duration and aetiology of bacteraemia following dental extractions. Oral Dis. 2007; 13(1): 56-62.

34. Davenport P, Land KJ. Isolation of Leclercia adecarboxylata from the blood culture of an asymptomatic platelet donor. Transfusion. 2007; 47(10): 1816-9.

35. Rodero L, Cuenca-Estrella M, Córdoba S, et al. Transient fungemia caused by an amphotericin B-resistant isolate of Candida haemulonii, J Clin Microbiol. 2002; 40(6): 2266-9.

36. McLaughlin RW, Vali H, Lau PC, et al. Are there naturally occurring pleomorphic bacteria in the blood of healthy humans? J Clin Microbiol. 2002; 40(12): 4771-5.

37. Nikkari S, McLaughlin IJ, Bi W, Dodge DE, Relman DA. Does blood of healthy subjects contain bacterial ribosomal DNA? J Clin Microbiol. 2001; 39(5): 1956-9.

38. Seifert H, Abele-Horn M, Fätkenheuer G, et al. Sepsis, Endokarditis, Katheterinfektionen, Teil 1. Expertengremium Mikrobiologisch-infektiologische Qualitätsstandards (MiQ), Qualitätssicherungskommission der Deutschen Gesellschaft für Hygiene und Mikrobiologie (DGHM). München:Urban \& Fischer; 2007.

39. Schrenzel J. Clinical relevance of new diagnostic methods for bloodstream infections. Int J Antimicrob Agents. 2007; 30 Suppl 1:S2-6.
40. Pletz MW, Wellinghausen N, Welte T. Will polymerase chain reaction (PCR)-based diagnostics improve outcome in septic patients? A clinical view. Intensive Care Med. 2011; 37(7): 1069-76.

41. Tsioutis C, Kritsotakis EI, Maraki S, Gikas A. Infections by pandrug-resistant gram-negative bacteria: clinical profile, therapeutic management, and outcome in a series of 21 patients. Eur J Clin Microbiol Infect Dis. 2010; 29(3): 301-5.

42. Daikos GL, Petrikkos P, Psichogiou M, et al. Prospective observational study of the impact of VIM-1 metallo-beta-lactamase on the outcome of patients with Klebsiella pneumoniae bloodstream infections. Antimicrob Agents Chemother. 2009; 53(5): 1868-73.

43. Drusano GL, Lodise TP. Saving lives with optimal antimicrobial chemotherapy. Clin Infect Dis. 2013; 56(2): 245-7.

44. Sime FB, Roberts MS, Peake SL, Lipman J, Roberts JA. Does beta-lactam pharmacokinetic variability in critically ill patients justify therapeutic drug monitoring? A systematic review. Ann Intensive Care. 2012; 2(1):35.

45. Tröger U, Drust A, Martens-Lobenhoffer J, Tanev I, Braun-Dullaeus RC, Bode-Böger SM. Decreased meropenem levels in Intensive Care Unit patients with augmented renal clearance: benefit of therapeutic drug monitoring. Int J Antimicrob Agents. 2012; 40(4): 370-2.

46. Falagas ME, Tansarli GS, Ikawa K, Vardakas KZ. Clinical outcomes with extended or continuous versus short-term intravenous infusion of carbapenems and piperacillin/tazobactam: a systematic review and meta-analysis. Clin Infect Dis. 2013; 56(2): 272-82.

47. Dulhunty JM, Roberts JA, Davis JS, et al. Continuous infusion of beta-lactam antibiotics in severe sepsis: a multicenter double-blind, randomized controlled trial. Clin Infect Dis. 2013; 56(2): 236-44.

48. Siddiqui S, Razzak J. Early versus late pre-intensive care unit admission broad spectrum antibiotics for severe sepsis in adults. Cochrane Database Syst Rev. 2010; 6(10): CD007081.

49. Dierkes C, Ehrenstein B, Siebig S, Linde HJ, Reischl U, Salzberger B. Clinical impact of a commercially available multiplex PCR system for rapid detection of pathogens in patients with presumed sepsis. BMC Infect Dis 2009; 9:126.

50. Lehmann LE, Hunfeld KP, Steinbrucker M et al. Improved detection of blood stream pathogens by real-time PCR in severe sepsis. Intensive Care Med. 2010; 36(1): 49-56.

51. Bloos F, Sachse S, Kortgen A, et al. Evaluation of a Polymerase Chain Reaction Assay for Pathogen Detection in Septic Patients under Routine Condition: An Observational Study. PLoS ONE. 2012; 7(9): e46003.

52. Clec'h C, Fosse J-P, Karoubi P, et al. Differential diagnostic value of procalcitonin in surgical and medical patients with septic shock. Crit Care Med. 2006; 34(1): 102-7.

53. Brunkhorst FM, Reinhart K. Diagnosis and causal treatment of sepsis. Internist (Berl). 2009; 50(7): 810-6.

54. Wacker C, Prkno A, Brunkhorst FM, Schlattmann P. Procalcitonin as a diagnostic marker for sepsis: a systematic review and meta-analysis. Lancet Infect Dis. 2013; 13(5): 426-35.

55. Prkno A, Wacker C, Brunkhorst FM, Schlattmann P. Procalcitonin-guided therapy in intensive care unit patients with severe sepsis and septic shock - a systematic review and meta-analysis. Crit Care. 2013; 17(6): R291.

56. Reinhart K, Brunkhorst FM, Bone HH, et al. Prävention, Diagnose, Therapie und Nachsorge der Sepsis. In: Reinhart K, Brunkhorst FM, eds. Sepsis. Stuttgart:Georg Thieme Verlag KG; 2010. 
57. Kumar A, Roberts D, Wood KE. Duration of hypotension before initiation of effective antimicrobial therapy is the critical determinant of survival in human septic shock. Crit Care Med. 2006; 34(6): 1589-96.

58. Reinhart K, Brunkhorst FM, Bone HG, et al. Diagnosis and therapy of sepsis: Guidelines of the German Sepsis Society. Internist. 2006; 47(4): 356-73.

59. Christ-Crain M, Jaccard-Stolz D, Bingisser R, et al. Procalcitonin-guidance of antibiotic therapy in community-acquired pneumonia. Am J Respir Crit Care Med. 2006; 174(1): 84-93.

60. Christ-Crain M, Jaccard-Stolz D, Bingisser R, et al. Effect of procalcitonin-guided treatment on antibiotic use and outcome in lower respiratory tract infections: cluster-randomised, single-blinded intervention trial. Lancet. 2004; 363(9409): 600-7.
61. Schuetz P, Christ-Crain M, Thomann R, et al. Effect of procalcitonin-based guidelines vs standard guidelines on antibiotic use in lower respiratory tract infections: the ProHOSP randomized controlled trial. JAMA. 2009; 302(10): 1059-66.

62. Nobre V, Harbarth S, Graf JD, Rohner P, Pugin J.Use of procalcitonin to shorten antibiotic treatment duration in septic patients. Am J Respir Crit Care Med. 2008; 177(5): 498-505.

63. Panacek E. Neutralization of the TNF by a monoclonal antibody improves survival and reduces organ dysfunction in human sepsis: results of the Monarcs trial. Chest. 2000; 118:88.

64. Bernard GR, Vincent JL, Laterre PF, et al. Efficacy and safety of recombinant human activated protein $\mathrm{C}$ for severe sepsis. N Engl J Med. 2001; 344(10): 699-709.

\section{Correspondence to/Autor za korespondenciju}

Frank M. Brunkhorst,

Salvador-Allende-Platz 27, 07747 Jena

E-Mail: frank.brunkhorst@med.uni-jena.de

Tel: +49 / 3641 / 9323381, Fax: +49 / 3641 / 9396669 
